\title{
Falske fossiler i lak og...lim - for fuld skrue
}

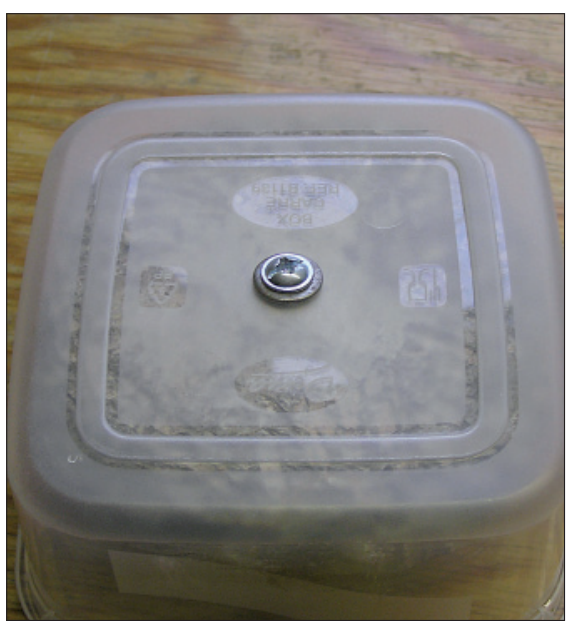

Fossil på dåse! (Foto: Forfatteren)

Af Niels Hansen, Sydsjcellands Amatørgeologiske Forening

Det kan godt være, at man tager på stenmesse med et uskyldigt ønske om at komme hjem med nogle flotte fossiler i sten. Meeeen nymodens stoffer som for eksempel lak er ved at fortrænge de gode gamle geologiske materialer fra markedet, så man må hellere lige kigge en ekstra gang på varerne, inden man køber!

På bagsiden af GeologiskNyt 6/05 blev læseren indviet i de noget alternative "fossiler", som jeg og et andet medlem af Sydsjællands Amatørgeologiske Forening havde

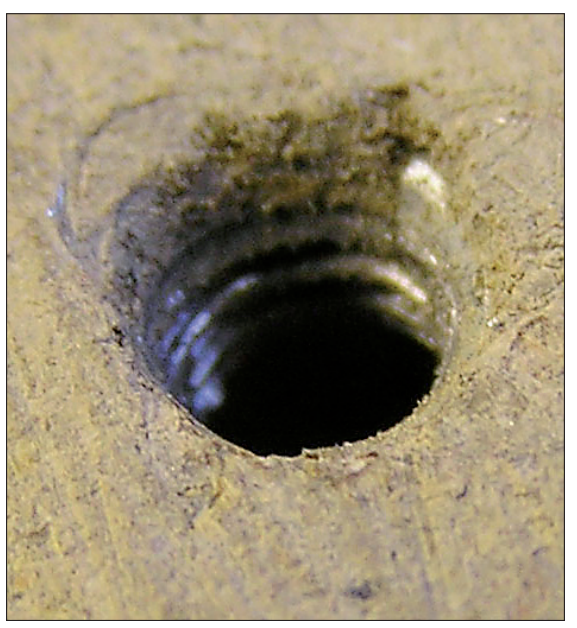

"Indbygget" gevind. (Foto: Forfatteren)

købt på Hamburg-messen i 2004, hvor der bl.a. var en hul trilobit iblandt. I december 2005 indkøbte jeg så et par mosasaurerkæber og en trilobit til nærmere studium.

\section{Lim og skrue}

Trilobitten var en Dicranurus monstrosus, en flot fyr til ca. $300 \mathrm{kr}$., der var skruet fast i en plastikæske. Det var en lufttæt æske (som en Tupperware), og da jeg dagen efter åbnede æsken, stank der af to-komponent lim. Ydermere viste det sig, at da jeg skruede skruen i bunden ud, var der indstøbt et gevind i "stenen"; så var det jo åbenbart for enhver, at her var der tale om en kopi.

\section{Tillakket}

Men hvad med trilobitten? Flot var den jo,

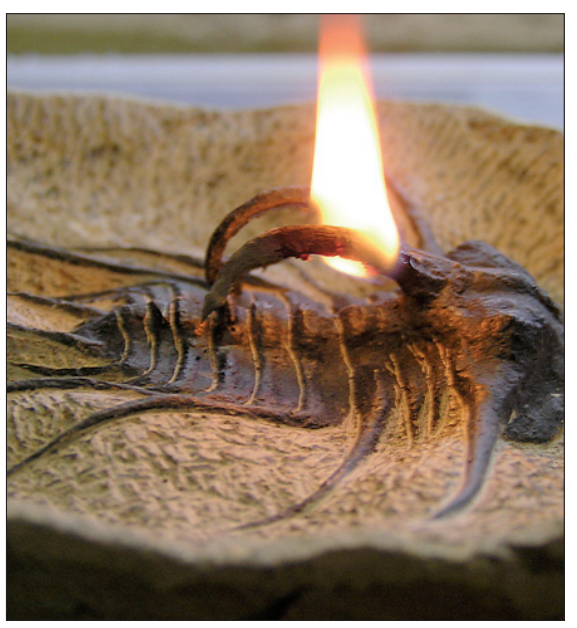

Trilobit klcedt i lak. (Foto: Forfatteren)

men jeg regnede nu med, at den var lavet af lak eller lim. Jeg brækkede et stykke af en af de flotte pigge på hovedet, og den viste sig at være lavet af lak.... Det endelige bevis kom, da jeg satte ild til, og den brændte med en flot, men sodende flamme.

\section{Snydt eller ej}

Nu kan man så spekulere over, om jeg er blevet snydt eller ej. Jeg har undersøgt prisniveauet på verdensplan, og en sådan ægte trilobit koster over $7.000 \mathrm{kr}$., så hvis man har sat sig ind i priser og kvalitet/ægthed på forhånd, kan man ikke være i tvivl om, at det er en efterligning, man køber.

Men for den udenforstående messegæsts skyld, syntes jeg godt, at forhandlerne kunne skrive det.

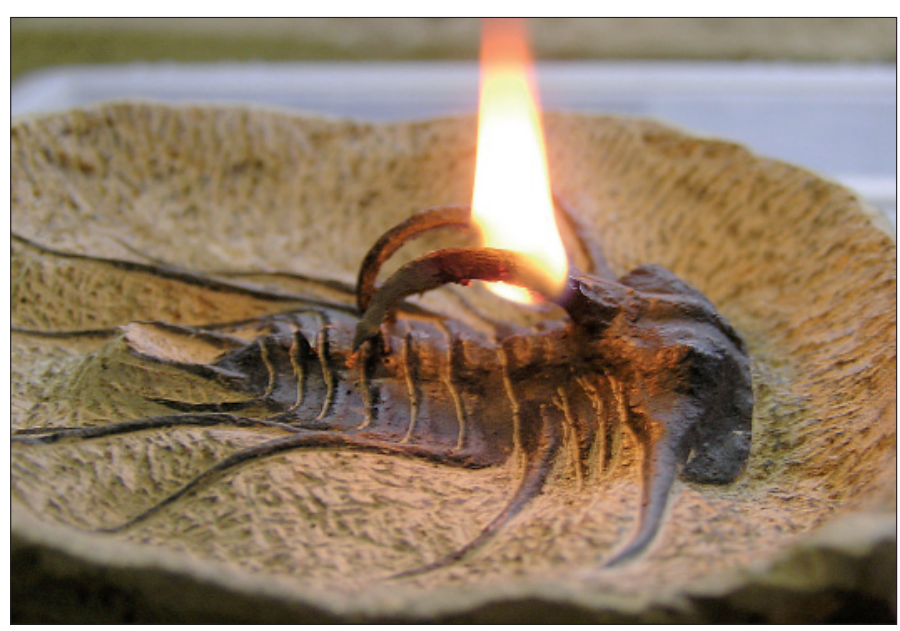

Ildprøven afslører trilobittens sande identitet. (Foto: Forfatteren)

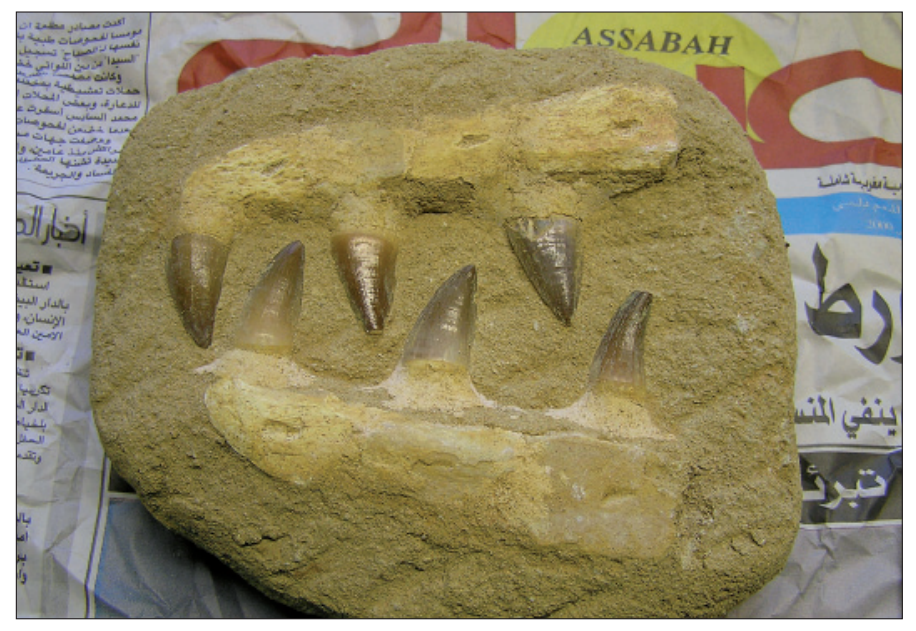

Et typisk eksempel på en mosasaurkcebe. (Foto: Forfatteren) 


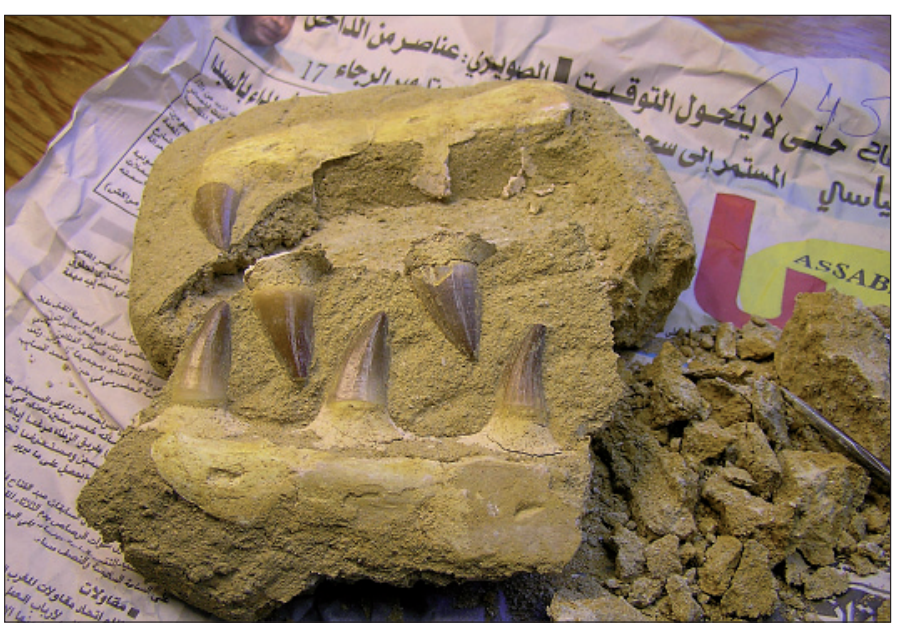

UPS! Støbt af to omgange....(Foto: Forfatteren)

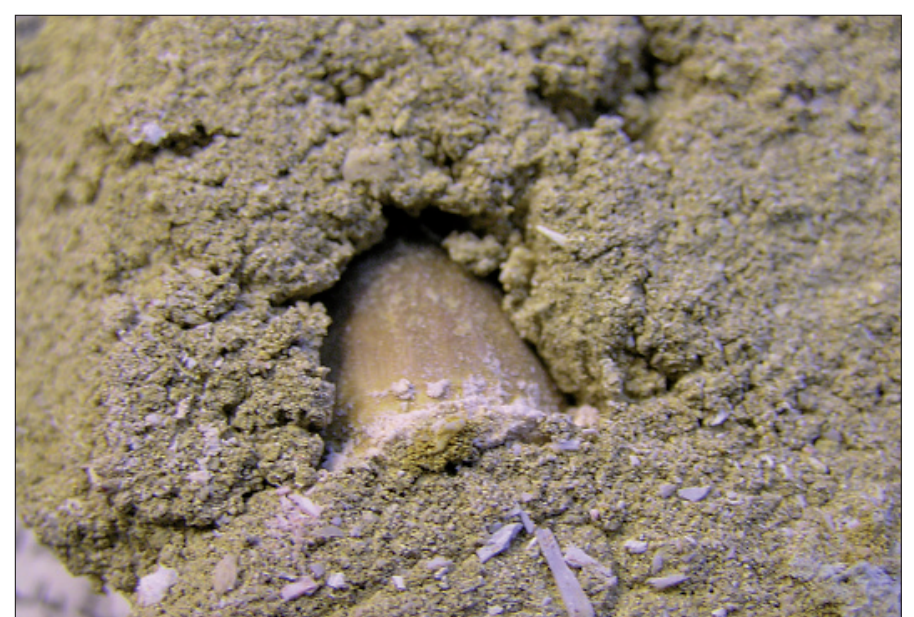

En kabe i opløsning. (Foto: Forfatteren)

\section{Af den rette stobning}

Mosasaurerkæberne blev naturligvis også underkastet et nøjere studium. Først fjernede jeg så meget af "sandstenen", at jeg kunne se tykkelsen af kæbeknoglen, som viste sig at være tyndere end tænderne. En lille skillelinie i stenen afslørede, at den var støbt af to omgange, en skruetrækker ind og et lille vip, og den øverste plade med kæberne fløj af. Når stykket blev vendt, var det tydeligt, at det var en støbning og ikke et sediment.

Det viste sig, at "stenen" var støbt af grus og en vandbaseret lim, for jeg tog stykket og holdt det ned i et fad med varmt vand, og på under et minut løb gruset ud mellem mine fingre! Jeg stod så tilbage med 6 ægte tænder, 7 knoglestykker savet ud af et eller andet og en grusbunke, alt sammen for $6 €$.
Her gør det samme sig gældende med hensyn til pris for ægte kæber, som koster tusindvis af kroner, hvis de vel og mærke er ægte!

\section{Så ved man dét!}

Jeg mødte en norsk palæontolog på Hamburg-messen. Han havde forsket i falske fossiler, og han vurderede, at $90 \%$ af trilobitterne dernede var falske!

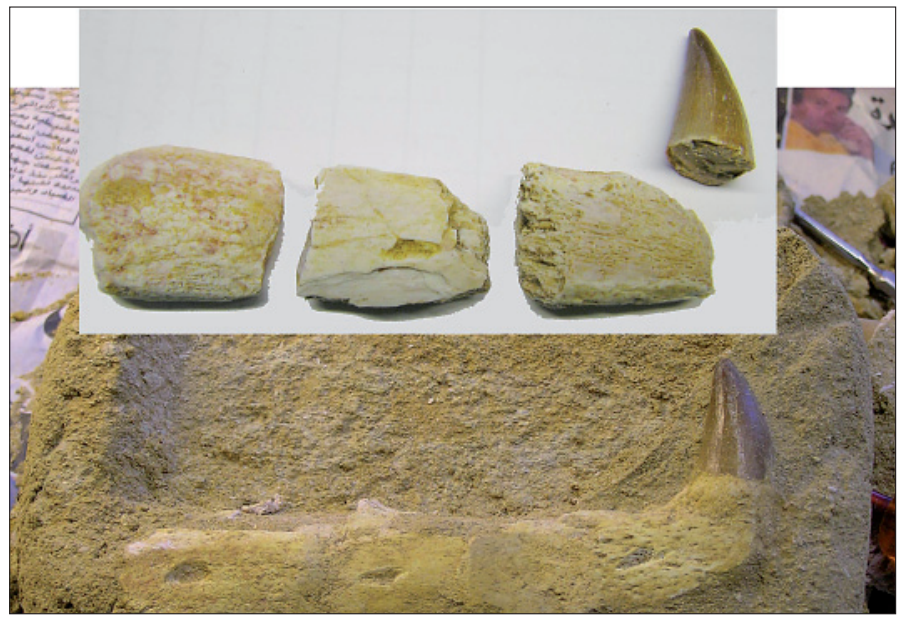

"Kobbeknoglen" kan inddeles i flere segmenter. (Foto: Forfatteren)

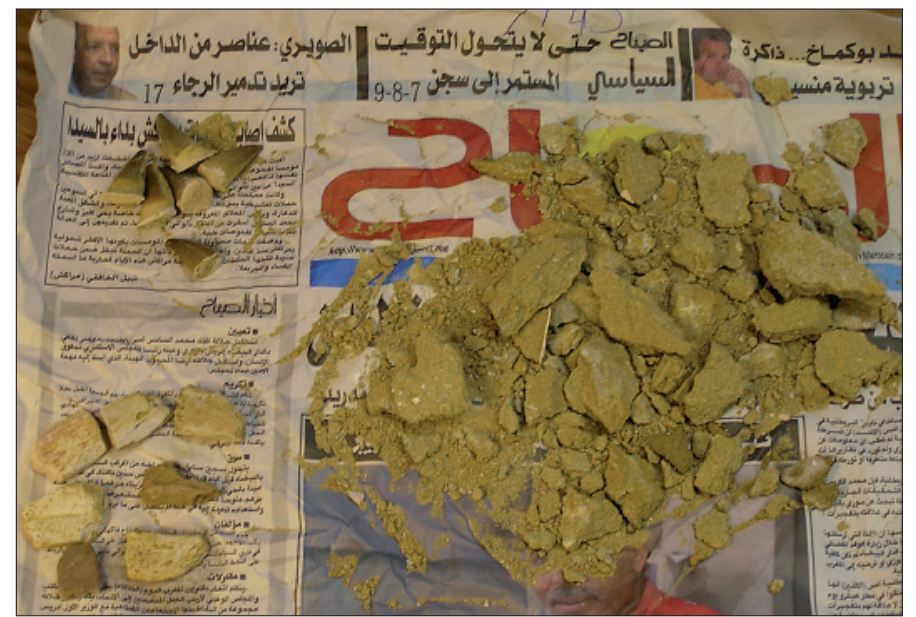

Hele det komplette "gør-det-selv-samlescet".(Foto: Forfatteren) 